\title{
New synonym and new records of craneflies (Diptera: Tipuloidea) in China
}

\section{Новый синоним и новые находки типулоидных двукрылых (Diptera: Tipuloidea) дяя фауны Китая}

\author{
Nikolay M. Paramonov ${ }^{1}$, Valentin E. Pilipenko \\ Н.М. Парамонов ${ }^{1}$ В.Э. Пимипенко
}

\footnotetext{
${ }^{1}$ Zoological Institute, Russian Academy of Sciences, Universitetskaya emb. 1, Saint Petersburg 199034, Russia. E-mail: param@zin.ru. Corresponding author.

Зоологический институт Российской академии наук, Университетская наб. 1, Санкт-Петербург 199034, Россия.

2 Lomonosov Moscow State University, Leninskie Gory, Moscow 119991, Russia.

Московский государственный университет им. М.В.Ломоносова, Ленинские горы, Москва 119991, Россия.
}

KEYWORDS: Diptera, Cylindrotomidae, Limoniidae, Tipulidae, new synonym, new records, China, craneflies. КЛЮЧЕВЫЕ СЛОВА: Diptera, Cylindrotomidae, Limoniidae, Tipulidae, новый синоним, новые находки, Китай, комары-долгоножки.

ABSTRACT. Genus Prionocera Loew, 1844 and six species from families Cylindrotomidae, Limoniidae and Tipulidae are newly recorded from China: Phalacrocera replicata (Linnaeus, 1758) (Cylindrotomidae); Austrolimnophila (Austrolimnophila) asiatica (Alexander, 1925), Dicranomyia (Dicranomyia) distendens distendens Lundstrom, 1912 (Limoniidae); Angarotipula rubzovi (Savchenko, 1961); Prionocera pubescens Loew, 1844 and Tipula (Odonatisca) longicauda Matsumura, 1906 (Tipulidae). Tipula (Vestiplex) pallitergata Alexander, 1934 is indicated for the first time for the Chinese province of Heilongjiang. Angarotipula heilongjiangana Yang et Yang, 1995 is a new synonym of Angarotipula rubzovi (Savchenko, 1961). Illustrations of the head, antennae, and terminalia of male and female $A$. rubzovi are given, as well as the distribution of this species in the Russian Far East.

РЕЗЮМЕ. Род Prionocera Loew, 1844 и 6 видов из семейств Cylindrotomidae, Limoniidae и Tipulidae впервые отмечены для фауны Китая: Phalacrocera replicata (Linnaeus, 1758) (Cylindrotomidae); Austrolimnophila (Austrolimnophila) asiatica (Alexander, 1925), Dicranomyia (Dicranomyia) distendens distendens Lundstrom, 1912 (Limoniidae); Angarotipula rubzovi (Savchenko, 1961); Prionocera pubescens Loew, 1844 и Tipula (Odonatisca) longicauda Matsumura, 1906 (Tipulidae). Tipula (Vestiplex) pallitergata Alexander, 1934 впервые отмечен для китайской провинции Хейлунцзян. Angarotipula heilongjiangana Yang et Yang, 1995 новый синоним для Angarotipula rubzovi (Savchenko, 1961). Даны иллюстрации головы, ан- тенны, терминалий самца и самки $A$. rubzovi, приведены дополнительные данные о его распространении на Дальнем Востоке России.

\section{Introduction}

The tipuloids (Diptera: Tipuloidea) form a large superfamily of Diptera, which includes the four families Cylindrotomidae, Limoniidae, Pediciidae and Tipulidae. The world fauna numbers more than 15600 species. The fauna of China contains 1344 species and subspecies [Oosterbroek, 2021], and active study on this fauna continues [Men, 2015, 2020; Men at el., 2015, 2016, 2017, 2018, 2019a, b; Ren, Yang 2017; Xue et al., 2019; Qian, Zhang, 2020; Starkevich et al., 2020]. However, the fauna of China still remains fragmentary and insufficiently studied.

\section{Material and methods}

Specimens for this study were collected during 20182019 field seasons using sweep nets and material was stored in $76 \%$ ethanol in the Diptera Collection of the Zoological Institute of Russian Academy of Sciences, Russia (ZIN). Inner structures of terminalia were studied after boiling in $10 \% \mathrm{NaOH}$ solution for 10 minutes. Specimens were studied with a Lomo microscope. A Nikon d7000 digital camera equipped with Tamron 70$300 / 4-5,6$ and EL-Nikkor 50/2,8 lenses were used to capture stacked images, which were then combined using the Helicon Focus software (http://www.

How to cite this article: Paramonov N.M., Pilipenko V.E. 2021. New synonym and new records of craneflies (Diptera: Tipuloidea) in China // Russian Entomol. J. Vol.30. No.2. P.182-188. doi: 10.15298/rusentj.30.2.13 
heliconsoft.com/heliconsoft-products/helicon-focus). All pictures were adjusted and assembled into plates with Adobe Photoshop CS2. Identified specimens were compared with type and non-type material from the Dipterological collection of Zoological Institute of Russian Academy of Sciences, Russia (ZIN). Distribution of species is given according to Oosterbroek [2021]. Terminology of morphological features generally follows that of Alexander and Byers [1981].

For citing label data on Holotype specimen, square brackets ([]) are used to indicate additional information not on the original label.

The material was collected in the course of a joint project between the Bastak Reserve (Russia, Jewish Autonomous Region) and the Honghe Reserve (China, Heilongjiang) by the senior researcher of the Bastak Reserve, A.A. Averin.

Depositories: ZIN - Zoological Institute of Russian Academy of Sciences, Saint-Petersburg, Russia; ZMUM - Zoological Museum of Moscow State University, Moscow, Russia.

\section{Taxonomic part}

\author{
Family Tipulidae \\ Subfamily Tipulinae \\ Angarotipula rubzovi (Savchenko, 1961) \\ Figs 1-19.
}

Tipula (Angarotipula) rubzovi Savchenko, 1961: 358-360. Type locality: Irkutskaya oblast, r.Belaya (White river).

Other references: Savchenko, 1964: 184; Liu, Yang, 2010: 61; Brodo, 2017: 12-34.

Angarotipula heilongjiangana Yang et Yang, 1995: 335. syn.n. Type locality: Heilongjiang, inv. Jiamusi. Other references: Liu Yang, 2010: 61; Brodo, 2017: 14.

TYPE MATERIAL EXAMINED: HOLOTYPE 1 male: Russia, Irkutskaya oblast, «[river] Belaya, V.S. [Vostochno-Sibirskiy] Kray, 13.vi.1935 (Rubtsov)». PARATYPUS: Russia, Irkutskaya oblast, 4 males, «st. Novo-Chunka, Irk. obl., $116 \mathrm{~km}$ ot Tayshet po Lene, 5.vi.1957 (K.B. Gorodkov)», «koshenie po osoke vdol pridor. kanavy». Amurskaya oblast, 1 male, 1 female, «rr. M. Pera i B. Ergel, mezhdur., Amur. obl., 25.vii.1957 (Zinoviev)». Respublika Buryatiya, 2 females, «Dureny, lev.b. Chikoy, Zabayk., 25.vii.1925, 5.viii.1925 (Mihno)»(ZIN).

ADDITION MATERIAL EXAMINED: China, province Heilongjiang: western border of the "Honghe" nature reserve, $47^{\circ} 44.998^{\prime} \mathrm{N}, 133^{\circ} 35.046^{\prime} \mathrm{E}, \mathrm{h}=52 \mathrm{~m}$. a.s.1., meadow vegetation on the banks of water bodies among willow thickets and small-leaved trees, 9 males, 18.v.2018 (A.A. Averin) (ZIN). Russia, Khabarovsky kray, Imeni Poliny Osipenko District, 5 km N settlement Briakan, 1 male, 21.vii.2006 (S. Holin) (ZMUM). Primorsky kray, Khasansky District, Lake Khasan, 2 females, 12.vii.1962 (E.P. Narchuk) Spassky District, eastern shore of Lake Khanka: 1 male, 19.viii.1963; 20 km. W city Spassk-Dalny, 3 females, 19.viii.1963, sedge swamp (E.P. Narchuk); Ussuriysky Urban Okrug, settlement Gorno-Taezhnoe, 1 male, 09.viii.1963 (E.P. Narchuk). Amurskaya oblast, Svobodnensky District, settlement Klimoutsy, $40 \mathrm{~km}$ W city Svobodny, 1 female, 4.vi.1957; 1 female, 13.vii.1957; 2 males, 25.vii.1957 (A.G. Zinoviev). Respublika Buryatiya: Kyakhtinsky District, settlement Dureny, left bank of the river Chikoy, 1 male, 5.viii.1925 (Mihno) (ZIN); Severo-Baykalsky District, settlement Uoyan, 1 male, 17.vi.1976 (L.B. Volkova) (ZMUM).

DISTRIBUTION. The species is found in Russia in the south of Eastern Siberia (Irkutskaya oblast, Respublika Bur- yatiya) and in the Far East (Amurskaya oblast, Primorsky kray), and in Mongolia (Tov Province) [Brodo, 2017]. These are the first records for Heilongjiang Province (China) and for the Khabarovsky kray in Russia.

NOTES ON SYNONYMY. For China, seven species of the genus Angarotipula Lundstrom, 1907 are indicated [Liu, Yang, 2010; Oosterbroek 2021]. Angarotipula heilongjiangana Yang et Yang, 1995, is described from the Heilongjiang province of China. Study of the type material of $A$. heilongjiangana and of $A$. rubzovi, as well as additional material from the Heilongjiang province (China) and the border regions of Russia (Amurskaya oblast, Respublika Buryatiya, Primorsky kray and Khabarovsky kray), revealed the synonymy of these species.

DISCUSSION. Savchenko [1961] suggested that this species could be found in northeastern China; he suggested that "the findings of T. tumidicornis in Harbin by Mannheims (1953) should be attributed to T. rubzovi". Meantime, the inaccurate drawing of the terminalia of a male of $A$. rubzovi in the original description and the variability of the structural coloration served as bases for the description of a new species, A. heilongjiangana Yang et Yang, 1995. In the original description of $A$. rubzovi, on the illustration of the terminalia of the male [Savchenko 1961: p. 359, Fig. 213], the denticles of tergite IX were directed outward, but the written description made no mention of the direction of the apical denticles. The illustrations were made from a pinned dry type specimen, without detaching the terminalia and making the preparation. The terminalia were compressed and partially separated, so the tergite IX and its denticles were distorted. However, the apical denticles are directed straight back and do not bend outward on the specially prepared slides of male terminalia (Fig. 10).

In the description given by Savchenko [1961], it was indicated that the abdominal tergites had a smudgy brown central stripe. This was reflected as well in the taxonomic key by Liu and Yang [2010, p. 61]: "Tergites of abdomen with black or brown central stripe" (A. rubzovi) and "Tergites of abdomen uniform in color" (A. heilongjiangana). When analyzing the additional material (China, province Heilongjiang), we have found that the stripe on the abdomen may be poorly expressed or completely absent in the local population of some species (Figs 4-5). According to the taxonomic key proposed by Savchenko (ibid.), "...the first segment of flagellum is longer threefold than the first main antenna segment" ( $A$. rubzovi); according to that of Liu and Yang [2010], "Antenna with the first flagellomere is much longer than second flagellomere" (A. heilongjiangana). The study of additional material gives evidence that in certain populations there may be specimens that differ not only in the coloration of the antennal segments, but also in their length (Figs 1-2).

The material from Heilongjiang Province (China) was compared with the type specimen $A$. rubzovi, and they were found to be identical. Mr. Jinlong Ren (China Agricultural University, Beijing, China) kindly sent us the photographs of $A$. heilongjiangana from the same province, as well as photographs of the male terminalia of the type specimen of $A$. heilongjiangana. In turn, we sent Figures 6-14 (present study) of the male genitalia of $A$. rubzovi to Mr. Jinlong Ren for comparison with the type of $A$. heilongjiangana stored in the collection of China Agricultural University. It was determined that $A$. rubzovi Savchenko, 1961 and $A$. heilongjiangana Yang et Yang, 1995 were identical, therefore, the latter is a junior synonym.

The original photographs of the head, antennae, abdomen, and parts of the terminalia of both male and female of 

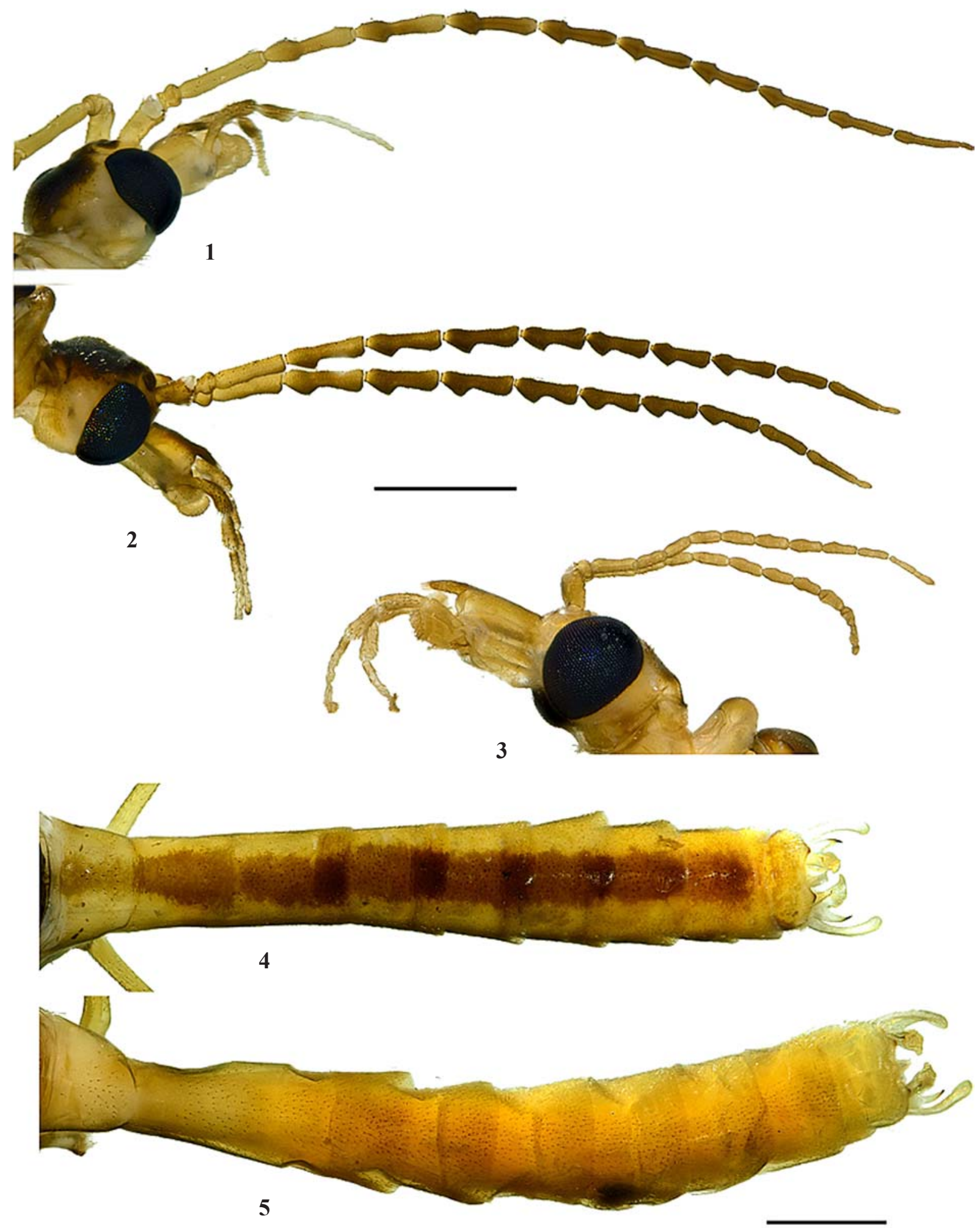

Figs 1-5 - Angarotipula rubzovi (Savchenko, 1961). 1-2 - male head and antenna, lateral view; 3 - female head and antenna, lateral view; 4-5 - male abdomen general, dorsal view; 4 - typical coloring with a central stripe; 5 - not typical coloring without a central stripe. Scale bars: $1 \mathrm{~mm}$.

Рис. 1-5 - Angarotipula rubzovi (Savchenko, 1961). 1-2 - самец, голова и антенна, сбоку; 3 - самка, голова и антенна, сбоку; 4-5 - самец, общий вид брюшка, сбоку; 4 - типичная окраска с центральной полосой; 5 - нетипичная окраска без центральной полосы. Масштаб: 1 мм. 
A. rubzovi are published for the first time in the present paper (Figs 1-19).

As indicated by Savchenko [1961], the antennae of $A$. rubzovi females are shorter and lighter colored than the males, they do not extend beyond the base of the wings, and the segments of the flagellum are cylindrical (Fig. 3). Termi-
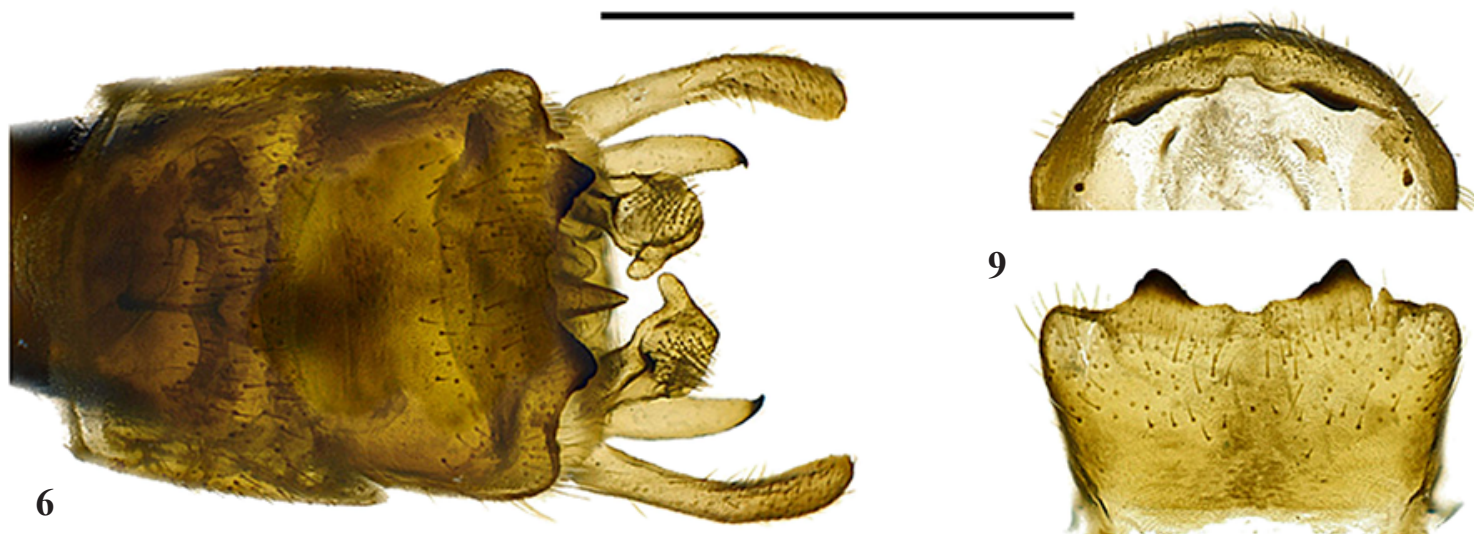

9

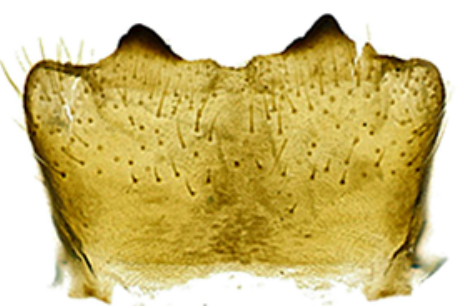

10
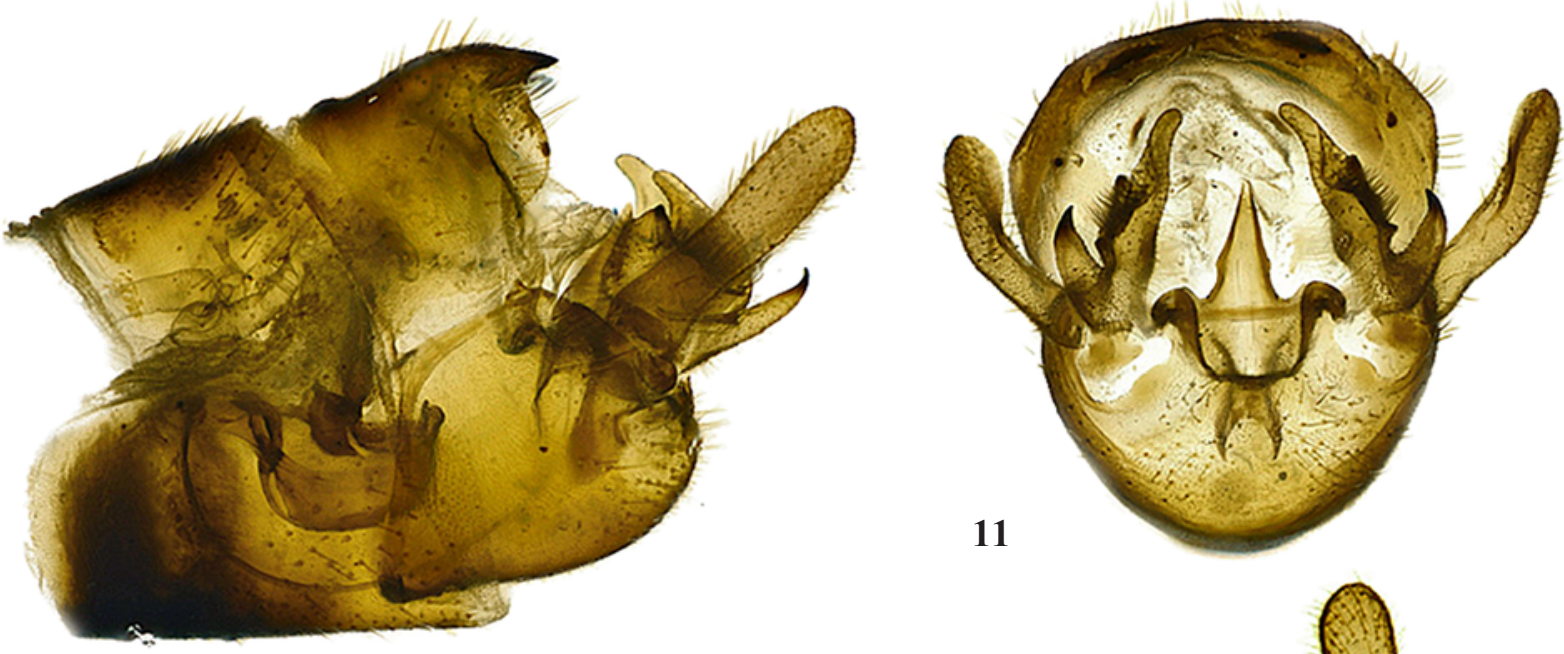

7

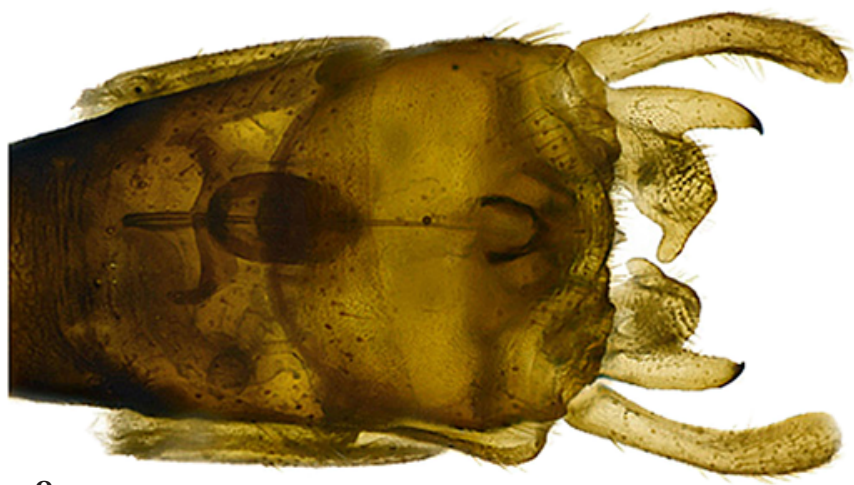

12
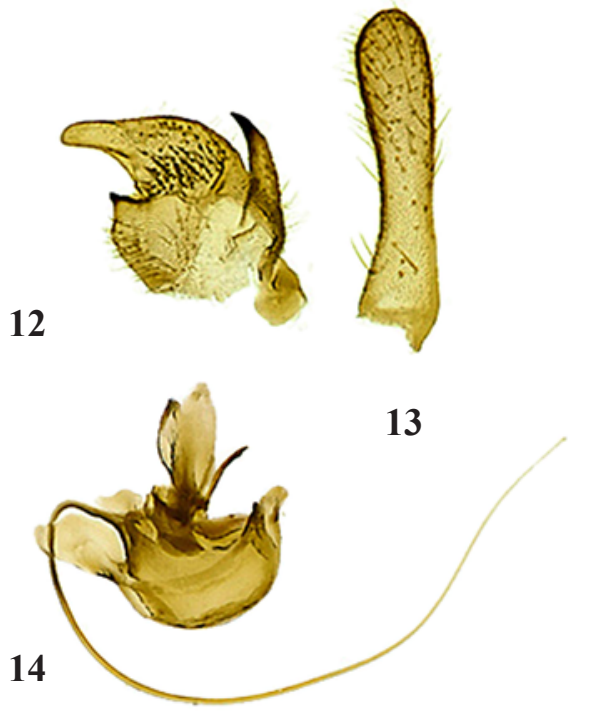

Figs 6-14 - Angarotipula rubzovi (Savchenko, 1961) male terminalia. 6 - general dorsal view; 7 - general lateral view; 8 - general ventral view; 9 - ninth tergite, posterior view; 10 - ninth tergite, dorsal view; 11 - general caudal view; 12 - left inner gonostylus, lateral view; 13 - left outer gonostylus, lateral view; 14 - sperm pump and appendages, lateral view. Scale bar: $1 \mathrm{~mm}$.

Рис. 6-14 - Angarotipula rubzovi (Savchenko, 1961) терминалии самца. 6- общий вид с дорсальной стороны; 7 - общий вид, сбоку; 8 - общий вид с вентральной стороны; 9 - девятый тергит, сзади; 10 - девятый тергит, с дорсальной стороны; 11 - общий вид, сзади; 12 - левый внутренний гоностиль, сбоку; 13 - левый внешний гоностиль, сбоку; 14 - семенная помпа с придатками, сбоку. Масштаб: $1 \mathrm{~mm}$. 
nalia of the female (Figs 15-19) are typical for the genus Angarotipula; they have short hypogynial valves and lanceolate cerci rounded at the end. The postero-lateral edge of sternite VIII has a large obtuse projection (lobe). The lateral side of sternite IX has a similarly shaped obtuse crest forming a lateral lobe of sternite IX.
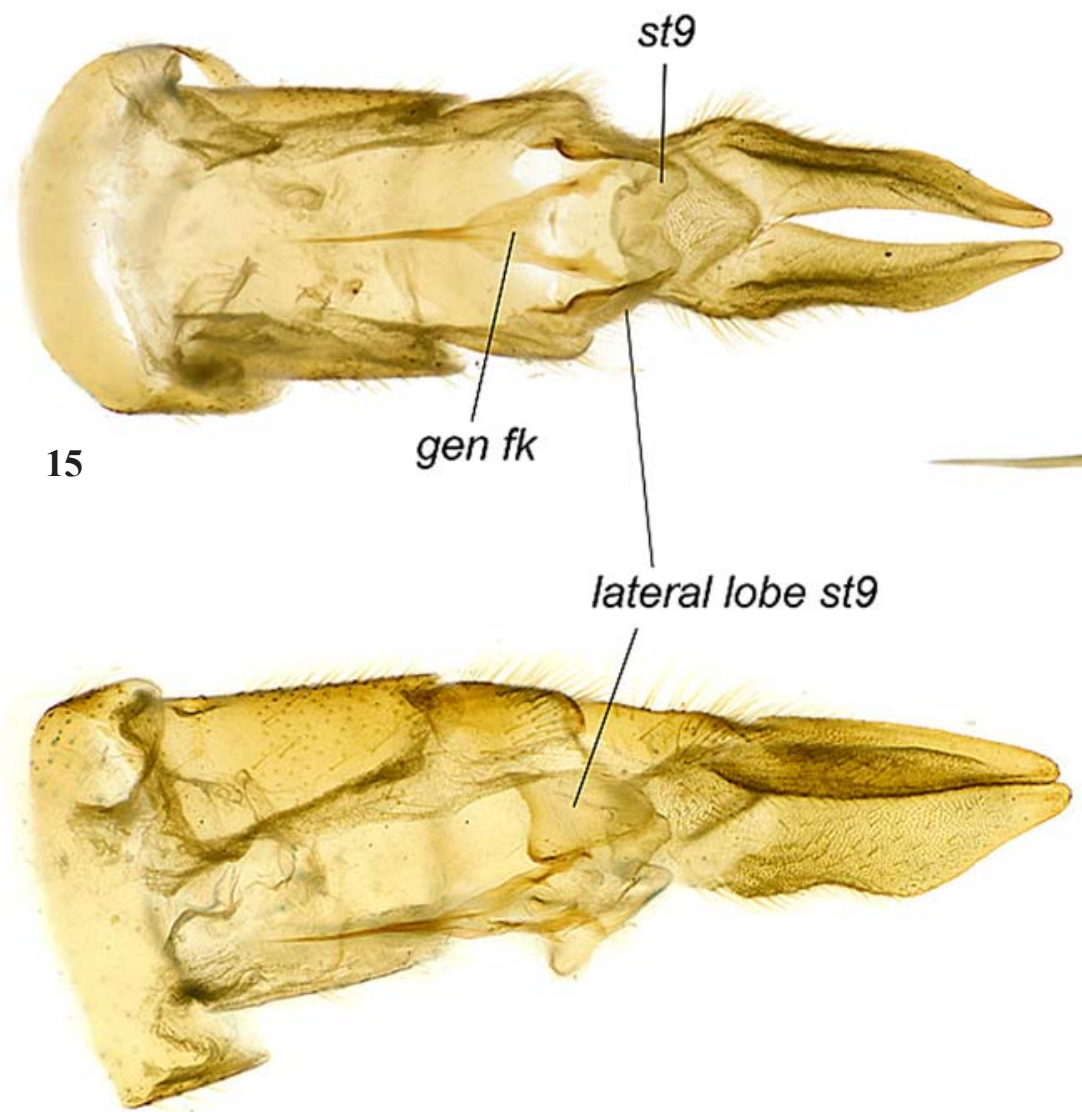

18

16

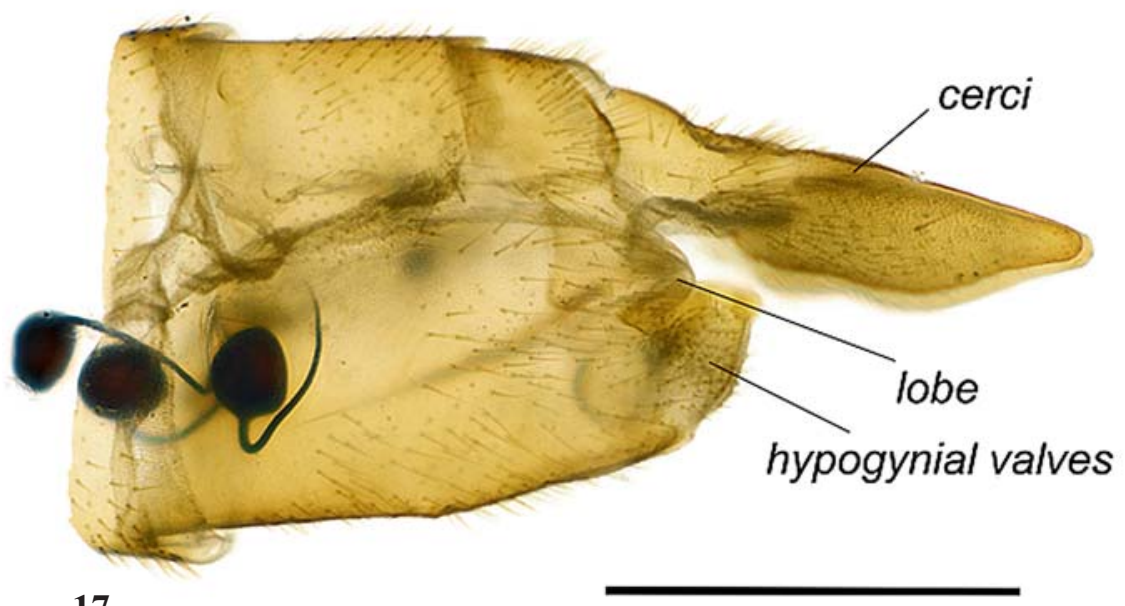

19

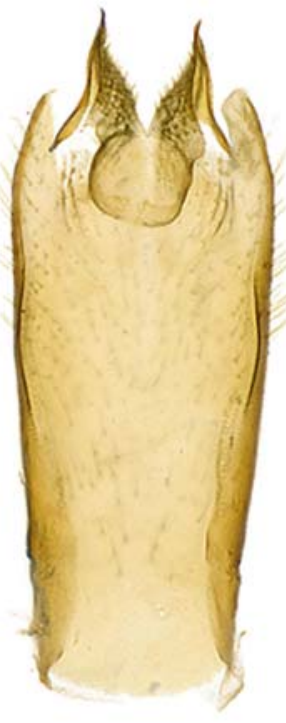

Figs 15-19 - Angarotipula rubzovi (Savchenko, 1961) female terminalia. 15 - general ventral view; 16 - general ventro-lateral view; 17 - general lateral view; 18 - eight sternite and hypogynial valves, dorsal view; 19 - genital fork (gen fk) ninth sternite, ventral view. Scale bars: Figs $15-18-1 \mathrm{~mm}$, Fig. $19-0.5 \mathrm{~mm}$.

Рис. 15-19 - Angarotipula rubzovi (Savchenko, 1961) терминалии самки. 15 - общий вид с вентральной стороны; 16 - общий вид с вентрально-латеральной стороны; 17 - общий вид, сбоку; 18 - восьмой стернит и вальвы, вид с дорсальной стороны; 19 генитальная вилка (gen fk) девятый стернит, с вентральной стороны. Масштаб: Рис. 15-18 - 1 мм, Рис. $19-0,5$ мм. 


\section{Prionocera pubescens Loew, 1844}

MATERIAL EXAMINED: China, province Heilongjiang, eastern border of the "Honghe" nature reserve, $47^{\circ} 51.154^{\prime} \mathrm{N}$, $133^{\circ} 46.375^{\prime} \mathrm{E}, \mathrm{h}=51 \mathrm{~m}$. a.s.1., meadow vegetation on the banks of water bodies among willow thickets and forests of small leaved trees, 1 male, 19.v.2018 (A.A. Averin).

DISTRIBUTION. A widespread Holarctic species; in the southeast Palearctic it is known from the Amurskaya oblast (Russia) and North Korea. The genus Prionocera and the species $P$. pubescens are reported from China for the first time.

REMARKS. The world fauna of the genus Prionocera includes 21 species, among which there are species both with a wide Holarctic distribution and those known from local habitats [Oosterbroek, 2021]. Previously, the genus Prionocera was not recorded for China, although it was known from Mongolia, Japan, North Korea, and the regions of Russia bordering on China.

Tipula (Odonatisca) longicauda Matsumura, 1906

MATERIAL EXAMINED: China, province Heilongjiang, prefectural city Hulunbuir, «Bacha Dao» Nature Reserve, 1 male, 04 05.vi.2019 (A.A. Averin).

DISTRIBUTION. Russia: FE (Magadanskaya oblast, Primorsky kray, Sakhalin, Kuril Is); Mongolia, South Korea, Japan (Hokkaido, Honshu, Shikoku, Kyushu). First record for China.

REMARKS. Earlier Savchenko [1964] suggested that this species could be found in the regions of China and Korea adjacent to Primorsky kray, as well as in central Japan in the north of the island of Honshu. Since then, the species has been found in all of the locations indicated by Savchenko.

Tipula (Vestiplex) pallitergata Alexander, 1934

MATERIAL EXAMINED: China, province Heilongjiang: western border of the "Honghe" nature reserve, $47^{\circ} 44.998^{\prime} \mathrm{N}$, $133^{\circ} 35.046^{\prime} \mathrm{E}, \mathrm{h}=52 \mathrm{~m}$. a.s.1., meadow vegetation on the banks of water bodies among willow thickets and small-leaved forests, 2 males, 18.v.2018; eastern border of the "Honghe" nature reserve, $47^{\circ} 51.154^{\prime} \mathrm{N}, 133^{\circ} 46.375^{\prime} \mathrm{E}, \mathrm{h}=51 \mathrm{~m}$. a.s.l., meadow vegetation on the banks of water bodies among willow thickets and small-leaved forests, 2 males, 19.v.2018 (A.A. Averin).

DISTRIBUTION. Russia: FE (Khabarovsky kray, Primorsky kray); Mongolia, China (Inner Mongolia). The record from Zabaikalsky kray [former Chitinskaya oblast] requires confirmation [Savchenko, 1964]. First record for China's Heilongjiang province.

\section{Family Cylindrotomidae \\ Subfamily Cylindrotominae}

\section{Phalacrocera replicata (Linnaeus, 1758)}

MATERIAL EXAMINED: China, province Heilongiiang, on the border of the bog landfill, $200 \mathrm{~m}$. from the office of the nature reserve "Honghe" in the Honghe village (Honghe farm), 47³5.087' N $133^{\circ} 30.222^{\prime} \mathrm{E}, \mathrm{h}=53 \mathrm{~m}$. a.s.1., meadow vegetation, small-leaved forest, willows on the banks of the canals, 1 female, 20.v.2018 (A.A Averin).

DISTRIBUTION. A widespread Holarctic species, in the southeast of the Palearctic occurs in Irkutskaya oblast and Respublika Sakha (Yakutiya) (Russia); Mongolia. First record for China.

REMARKS. The genus Phalacrocera Schiner, 1863 has 11 species, of which 7 species are found in the Oriental realm, three are Nearctic and one species has a Holarctic distribution. There are two species of the genus Phalacrocera in the China: Ph. formosae Alexander, 1923 (Taiwan) and $P h$. tarsalba Alexander, 1936 (Hainan). Both species belong to the Oriental realm [Oosterbroek, 2021].
Family Limoniidae

Subfamily Limnophilinae

Austrolimnophila (Austrolimnophila) asiatica (Alexander, 1925)

MATERIAL EXAMINED: China, province Heilongjiang, prefectural city Jiamusi, «Bacha Dao» Nature Reserve, N48,219125 E133,886072, 1 male, 4-5.vi.2019 (A.A. Averin).

DISTRIBUTION. Widespread in the south of Western and Eastern Siberia (Respublika Altay, Respublika Buryatiya) and the Russian Far East (Amurskaya oblast, Yevreyskaya avtonomnaya oblast, Primorsky kray, Sakhalin, Kuril Is). First record for China.

REMARKS. The genus Austrolimnophila Alexander, 1920 is mentioned as new for mainland China; previously Austrolimnophila with four species were noted for the fauna of the island of Taiwan [Oosterbroek, 2021].

\section{Subfamily Limoniinae}

\section{Dicranomyia (Dicranomyia) distendens distendens} Lundstrom, 1912

MATERIAL EXAMINED: China, province Heilongjiang, prefectural city Jiamusi, «Bacha Dao» Nature Reserve, N48,219125 E133,886072, 1 male, 4-5.vi.2019 (A.A. Averin).

DISTRIBUTION. Known from the Russian Far East (Primorsky kray, Kuril Is), South Korea. First record for China.

REMARKS. D. (s.str.) distendens has two subspecies, nominative and a subspecies differing in the color of $D$. (s.str.) $d$. pallida Savchenko, 1983. The status of the latter subspecies is still unclear and controversial [Podenas et al., 2019] and is indicated in this work as a nominative form.

Acknowledgments. We are grateful to Daria Martynova (Zoological Institute, Russian Academy of Sciences, SaintPetersburg, Russia) for the translation of the manuscript into English. Fenja Brodo (Canadian Museum of Nature, Ottawa, Canada) kindly read the manuscript, made contributive comments, and checked and improved the English. Vladimir Lantsov (Tembotov Institute of Ecology of Mountain Territories Russian Academy of Sciences, Nalchik, Russia) for his helpful notes. The authors thank Mr. Jinlong Ren (China Agricultural University, Beijing, China) for the photographs of the type specimen and additional information material on A. heilongjiangana. Sincere thanks also to A.A. Averin («Bastak» Nature Reserve, Birobidzhan, Russia), for the material collected and provided for study. Nikolay Paramonov's research was supported by the state research project AAAAA19-119020690082-8 and the Presidium RAS program no.41 "Biodiversity of natural systems and biological sources of Russia".

Competing interests. The authors declare no competing interests.

\section{References}

Alexander C.P., Byers G.W. 1981. Tipulidae // McAlpine J.F. et al. (eds.). Manual of Nearctic Diptera. Vol.1. Biosystematics Research Institute, Ottawa, Ontario. Monograph 27. P.153-190.

Brodo F. 2017. Taxonomic review of Angarotipula Savchenko, 1961 (Diptera: Tipulidae) in North America // Canadian Entomologist. Vol.150. P.12-34.

Liu Q., Yang D. 2010. Two new species of the genus Angarotipula Savchenko, with a key to world species (Diptera, Tipulidae) // Zootaxa. Vol.2653. P.60-68. 
Men Q.-L. 2015. Report on crane flies of the genus Tipula (Diptera: Tipulidae: Tipulinae) from Anhui Province, China // Acta Entomologica Musei Nationalis Pragae. Vol. 55. P.797-810.

Men Q.-L. 2020. Three new species of the subgenus Tipula (Sivatipula) from Yunnan and Tibet, China (Diptera: Tipulidae), with an updated key for Chinese species // Zoological Systematics. Vol. 45. P.59-68.

Men Q.-L., Lu Z., Sheng P., Gui X., Wang Z., Mu D. 2017. Taxonomy on crane flies in family Tipulidae and Limoniidae (Diptera: Tipuloidea) from Yaoluoping National Nature Reserve, Anhui, China // Zoological Systematics. Vol.42. P.476489.

Men Q.-L., Dong Y., Yue C., Cao Y., Xu Z.-K. 2018. Six new species of Dolichopeza (Nesopeza) from China (Diptera: Tipulidae)// Acta Entomologica Musei Nationalis Pragae. Vol.58. P.589608.

Men Q.-L., Tang L., Wu L.-M., Ji Z.-X., Li C.-H. 2018. Description of two new species in long-horned crane fly subgenus Tipula (Sivatipula) (Diptera: Tipulidae) from China // Zootaxa. Vol.4415. No.1. P.195-200.

Men Q.-L., Wang H., Sheng N., Zhao Q., Zhang J. 2019a. A new species of Tipulodina (Diptera: Tipulidae) from China // Entomotaxonomia. Vol.41. No.1. P.1-7.

Men Q.-L., Wang H., Sheng N., Zhao Q., Zhang J. 2019b. A new species of Brithura Edwards from China, with notes on its internal reproductive system (Diptera: Tipulidae) // Zoological Systematics. Vol.44. No.2. P.158-166.

Men Q.-L., Xue G.-X., Liu Y. 2015. A morphological study on reproductive system of Tipula (Yamatotipula) nova Walker (Diptera: Tipulidae) // Zoological Systematics. Vol.40. No.3. P.328-338.

Men Q.-L., Xue G., Sun, M., Sun, Z. 2017. Crane flies in the family Tipulidae (Diptera: Tipuloidea) from Dayaoshan National Nature Reserve, China, with description of one new species in the genus Indotipula and analysis of DNA barcodes // Entomotaxonomia. Vol.39. No.4. P.251-264.

Men Q.-L., Xue, G., Wang F. 2016. Taxonomy on crane flies from Mountain Huang, China, with descriptions of two new species (Diptera: Tipulidae) // Zoological Systematics. Vol.41. No.1. P.89-101.

Men Q.-L., Xue G-X., Yang X.M. 2016. Two new species of subgenus Sivatipula from China (Diptera: Tipulidae: Tipula) // Acta Entomologica Musei Nationalis Pragae. Vol.56. No.2. P.805-811.
Men Q.-L., Xue G., Yang H. 2015. Two new species of the genus Nephrotoma (Diptera, Tipuloidea, Tipulidae) from China with a key to species from mainland China // ZooKeys. Vol.532. P.117-136.

Men Q.-L., Xue G-X., Yu Y.-F., Yang L. 2016. New species of Dictenidia from China, with a key to species in China (Diptera: Tipulidae: Ctenophorinae) // Entomological News. Vol.126. No.1. P.36-42.

Men Q.-L., Young C.W., Starkevich P., Yu Y.-F., Lei X.-P. 2017. Two new species of Tipula (Vestiplex) from Southern China based on morphological and molecular data, with redescription of Tipula (Vestiplex) bicalcarata (Diptera, Tipulidae, Tipulinae) // ZooKeys. Vol.658. P.63-80.

Qian X., Zhang X. 2020. Two new Geranomyia Haliday (Diptera, Limoniidae) crane flies from Mount Jiulong in China, with an updated key to Chinese species // Zookeys. Vol.953. P.105-118.

Oosterbroek P. 2019. Catalogue of the Craneflies of the World. (Diptera, Tipuloidea: Pediciidae, Limoniidae, Cylindrotomidae, Tipulidae), online at: https://ccw.naturalis.nl (updated 14 January 2021; viewed 25 January 2021)

Podenas S., Seo H.Y., Kim T., Hur J.M., Kim A.-Y., Klein T.A., Kim H.C., Kang T.H., Aukstikalniene R. 2019. Dicranomyia crane flies (Diptera: Limoniidae) from Korea // Zootaxa. Vol.4595. No.1. P.1-110

Ren J., Yang D. 2017. Nephrotoma Meigen (Diptera, Tipulidae) from Xinjiang, China // Zootaxa. Vol.4353. No.3. P.551-567.

Savchenko E.N. 1961. [Crane-flies (Diptera, Tipulidae), Subfam. Tipulinae, Genus Tipula L., (part 1)] // Fauna SSSR. Nov. ser. 79. Nasekomye Dvukrylye (Diptera). T.2. Is.3. 487 p. [In Russian]

Savchenko E.N. 1964. [Crane-flies (Diptera, Tipulidae) new for the fauna of the far-eastern USSR] // Pratsi Instytutu Zoologii. Kiev. T.20. P.180-192 [in Ukrainian with Russian summary].

Starkevich P., Men Q.-L., Siveli D. 2020a. Redescriptions of the poorly known crane fly species Tipula (Vestiplex) scandens and Tipula (Vestiplex) subscripta from Tibet and Yunnan, China (Diptera, Tipulidae) // ZooKeys. Vol.917. P.127-140.

Xue G.-X., Men Q.-L., Zhang J., Zhao Q., Sheng N., Wang H.-X., Long J.-F. 2019. A new species of Tipulodina (Diptera: Tipulidae) from China, with description of the female internal reproductive system // ZooKeys. Vol.864. P.67-77.

Yang D., Yang J.[C.] 1995. Four new species of Tipulidae from North China (Diptera: Nematocera) // Acta Agriculturae Universitatis Pekinensis. Vol.21. No.3. P.332-336 [in Chinese, with English summary]. 